\title{
A preliminary survey of Kounounkan Forest, Guinea, West Africa
}

\author{
Adrian Barnett, Madeleine Prangley, Peter V. Hayman, Djiramba Diawara \\ and Jeremie Koman
}

Biological studies in Guinea have been very patchy, leaving much of the country almost unsurveyed. In 1992 the Fauna and Flora Preservation Society funded a 10-day field visit to Kounounkan, a relict forest at the northern edge of the Upper Guinea Forest Block. The survey found a variety of habitats and high biodiversity, including two vulnerable and one endangered species. Hunting pressure appears to be low and the site is very well suited for the development of further conservation initiatives.

\section{Introduction}

Compared with other countries in West Africa, the biology of the Republic of Guinea is not well known. Apart from botanical studies on the Fouta Djalon plateau (Schnell, 1968) and some recent studies of coastal avifauna (Altenburg and Van Der Kamo, 1991) the majority of work has taken place in the south-east of the country, either on Mount Nimba (see Lamotte, 1983, for a summary) or elsewhere (for example Bourque and Wilson, 1990, at Ziama and at Diécké). There are no countrywide survey data at all for some groups (for example crocodiles, Thorbjarnarson et al., 1992), and many of the IUCN/SSC Action Plans include basic surveys as a priority recommendation for Guinea (for example Oates, 1985; Lee et al., 1988; East, 1989; Schreiber et al., 1989; Foster-Turley et al., 1990).

There are six major vegetation types in Guinea (White, 1983) and the climate becomes progressively drier towards the north and east (Wilson, 1992). MacKinnon and MacKinnon (1986) estimated that some 74 per cent of the country was originally forested. Recent estimates for extant closed forest cover range from 8.33 per cent $(\mathrm{FAO}, 1988)$ to 4.33 per cent (République de Guinée, 1987) of Guinea's $245,857 \mathrm{sq} \mathrm{km}$. Wilson (1992) stated that rain forest (excluding mangroves) now covers some $4692 \mathrm{sq} \mathrm{km}$, or 1.9 per cent of the country's land area. Stuart and Adams (1990) considered the main cause of deforestation in Guinea to be agricultural clearance, exacerbated by immigration from degraded Sahelian regions to the north.

According to the IUCN (1988), protected areas cover some 4-5 per cent of the country. However, effectiveness of enforcement is complicated by logistic and financial problems (Cumming et al., 1990) and many of the protected areas are now severely degraded (Wilson, 1992). Several habitat types are not represented within the current protected areas system (Stuart and Adams, 1990).

\section{Site description and history}

Kounounkan covers 5032 ha $90 \mathrm{~km}$ south-east of the capital, Conakry, near the small town of Moussayah, Forécariah Province (Figure 1). It contains mainly old (greater than 150 years) secondary closed canopy forest, although marsh and natural savannah are also present. The climate is monsoonal with rain from April to October. The forest lies on the edge of the coastal scarp, at the geological junction between the plateau of the Fouta Djalon and the coastal plain of Guinée Maritime, on a massif of Devonian sandstone, a southerly outlier of the Fouta Djalon formation. The massif rises from 50 to $1094 \mathrm{~m}$ above the coastal plain. 




Figure 1. Map showing the location of Kounounkan Forest in Guinea, West Africa.

Riverine erosion has dissected the massif into several plateaux with very steep sides. The forest area has also appeared on maps under the name of 'Kamalayah' (Bournonville, 1967; Wilson, 1992). The coastal plain was widely deforested during colonial times to make way for banana plantations and there are few extensive areas of forest remaining in the region. Firewood collection is considered to be the most substantial modern threat to the fragments of scarp forest that remain.

As long ago as 1954 the colonial French administration was planning the protection of Kounounkan as 'one of the last relicts of primary forest in lower Guinea' (Rouanet, 1954). Although the process of its incorporation into the protected areas network was interrupted by the upheavals that followed independence in 1958, the forest has always been regarded as a 'classified forest' by local people. This, coupled with local beliefs that parts of it are sacred, and the general inaccessibility of the area have combined to protect it. According to Wilson (1992), this area may represent the northernmost extension of the Upper Guinea Rainforest Block. Old government documents in the archives at the Direction Nationale des Forêts et de la Chasse (DNFC), show that the forest has been the subject of very little scientific activity. A visit to the Diglitili Valley by the French botanist Maurice Schnell in the early 1950s appears to be the only previous scientific study. The current survey was the result of the desire by the DNFC to incorporate Kounounkan into the existing protected areas network. To make the best use of scarce resources they wished the conservation value of the forest to be assessed before doing this.

\section{The current survey}

In a 4-week study visit in NovemberDecember 1992, a team of three British and four Guinean biologists spent 64 man-days at Kounounkan. Three fieldwork sites were visited and inventories of the birds (P.V.H.), mammals (A.B. and M.P.) and vascular plants 
(J.K.) were undertaken. At the same time, D.D. carried out interviews (in the regional language, Susu) with local communities to gain insights into their hunting practices and attitudes towards the forest and towards conservation plans for it.

Standard methodologies were followed: extensive surveys, timed species counts (TSCs) (Pomeroy and Tengecho, 1986) and targeted searches for birds; direct observation and study of spoor for larger mammals and trapping for small ones. Attempts were made to cover all habitat types at each of the three study sites. One of us (J.K.), accompanied by a local DNFC employee, traversed the forest with several multi-day walks, identifying plants en route. Work with local communities relied on D.D.'s previous experience with the area's villagers, augmented by methodologies derived from hunting surveys conducted elsewhere (Cunha and Barnett, 1989; Bellamy, 1993).

\section{Results}

One hundred and thirty-five species of birds, 33 species of mammals and 274 species of vascular plants were recorded. The white-necked picathartes Picathartes gymnocephalus was sighted three times and two nest sites were found. This species is regarded as vulnerable by Collar and Stuart (1985). In addition, four Candidate Threatened Species (CTS) were recorded: Ahanta francolin Francolinus ahantensis, yellow-casqued hornbill Ceratogymna elata, Sharpe's apalis Apalis sharpii and redcheeked wattle eye Platysteira blissetti. Nine species of primate, three carnivores and 10 rodents were observed. Six other species (three carnivores, plus bongo Taurotragus eurycerus, forest pig Potamochoerus or Hylochoerus and duiker sp.) were recorded by field signs. Another five species, not recorded by us, were reported by local communities.

The western diana monkey Cercopithecus diana diana is listed as vulnerable by Lee $e t$ al., (1988) and the western chimpanzee Pan troglodytes verus is listed as endangered. Judging from the distribution and frequency of chimpanzee vocalizations heard during fieldwork, $P$. troglodytes must be quite common at Kounounkan. Diana monkeys were reported from one area only. Of the other species of mammal, sooty mangabey Cercocebus torquatus atys, Campbell's mona monkey Cercopithecus $c$. campbelli and western black-and-white colobus Colobus polykomos polykomos were commonly encountered in the closed forest.

This survey revealed the presence of tree species such as Afzelia africana, Aningeria altissima, Cola gigantea, Morus mesozygia which place Kounounkan, as 'drier peripheral semievergreen Guineo-Congolian rain forest' in the vegetation classification scheme of White (1983). The botanical work showed that the forest is an area of mixed primary and secondary closed forest with natural savannah (characterized by Annona senegalensis, Parkia biglobosa, Pterocarpus erinaceus and Terminalia glaucescens) and man-made savannah. Regenerating farmbush is present in the peripheral zones.

In co-operation with their chiefs, questions on hunting were presented to the members of six of the small (100-500 people) villages around Kounounkan. There were a total of 10 hunters in these villages. They said they used only shotguns and shunned traps and nooses. Older hunters preferred to hunt in the farmbush, only the younger ones used the deep forest. There are no local taboos on hunting of any forest animal, although the two species of wild pigs are not eaten because of the restrictions of Islamic Law. Reportedly, bushmeat was an important item of diet, but its use was not commercialized. Commercialization of non-meat products was said to be limited to the sale of skins to travelling musicians for instrument manufacture. Although there were said to be fewer mammals now than in the past, two or three hours hunting was said to yield an average of two animals. No regular market selling bushmeat was said to exist in the nearby town of Moussayah, and none was observed during our stay. Fresh and dried freshwater fish appeared to be the only meat commonly sold in the market at Moussayah. Primates were not reported to be punitively 
hunted as agricultural pests.

Hill-stream catfish (Amphilius sp.) were found in a small stream in the Diglitili Valley.

\section{Discussion}

According to Morel and Morel (1988), Picathartes has been recorded in south-east Guinea (see Brosset, 1984) but not from southwest Guinea. Richards (1982) included an unconfirmed record of Picathartes gymnocephalus in his list of birds from Kakoulima, making our records the first confirmed sightings of the species in south-west Guinea. The confirmation of the presence of this species at Kounounkan represents a north-westerly range extension of approximately $125 \mathrm{~km}$, the nearest known birds being on the Freetown Peninsula, Sierra Leone (Allport, 1991). The record for Kounounkan represents the most westerly confirmed record for the species to date. Picathartes gained an index of 0.6 in the TSC results, which is high for a species normally considered to be elusive and difficult to see and may indicate a high population density of this species at the sites visited.

According to Lee et al., (1988) Cercopithecus $d$. diana has been recorded previously in the Seredou area of Guinea (some $300 \mathrm{~km}$ ESE of Kounounkan). Pan is widespread in Guinea (Sugiyama and Soumah, 1988), and the country may hold 60 per cent of the western subspecies (Lee et al., 1988). Bournonville (1967), who conducted a 100-day field survey of Pan in western Guinea, obtained reports that chimpanzee calls were frequently heard at 'Kamalayah' (=Kounounkan), but did not visit the site himself. His nearest sighting was some $40 \mathrm{~km} \mathrm{NW}$ of the present location. It must be considered unlikely that chimpanzees now survive at many of Bournonville's sites (especially those near Conakry).

The avifauna of Kounounkan closely resembles that of Gola Forest, eastern Sierra Leone (Allport et al., 1989) and Western Area Forest, western Sierra Leone (Ausden and Wood, 1990). The latter is ornithologically more closely allied to Kounounkan. The best-studied bird communities in Guinea (Ziama,
Diécké and Mount Nimba [Bourque and Wilson, 1990]), have bird communities that have much in common with those in adjacent parts of Liberia, Côte d'Ivoire and in the Gola Forest, Sierra Leone. The Outamba-Kilimi area of Sierra Leone lies to the north-east of Kounounkan and has an avifauna with a high percentage of savannah and open woodland species (Harding and Harding, 1982; Happel 1984). At Kounounkan, the composition of the bird community is what one might expect in a forest with comparatively low hunting intensity at the natural edge of the Upper Guinea Forest Block. Some forest bird species commonly present in Gola and Western Area Forests were notable by their absence from Kounounkan (for example, icterine greenbul Phyllastrephus icterinus), while dry country species such as vinaceous dove Streptopelia vinacea, red-collared widowbird Euplectes ardens, red-billed firefinch Lagonosticta senegala and martial eagle Polemaëtus bellicosus were present at Kounounkan but have not been recorded from either Gola or the Western Area Forest, Sierra Leone.

A similar pattern is also found in the results of the mammal studies. Thus, dry country species such as the green monkey Cercopithecus aethiops and olive baboon Papio anubis were recorded alongside forest species like Campbell's mona monkey, diana monkey, lesser white-nosed monkey $C$. petaurista buttikoferi and western black-and-white colobus.

The hunting pressure on Kounounkan appears to be relatively low compared with that reported elsewhere in African forests (for example Robinson, 1971; Jeffrey, 1977; Starin, 1989; Ausden and Wood, 1990; Falconer, 1992; Sodeinde and Adedipe, 1994). The reasons for believing this include the high apparent density of primates in Kounounkan [a group that is often preferentially hunted for bushmeat (Martin, 1991)], the monkeys' lack of fear of humans and the often-observed presence of monkeys near villages. Colobines are generally considered to be very sensitive to hunting (Martin, 1991), yet the black-and-white colobus was seen frequently at Kounounkan. The encounter rates with troops in this study 
was in marked contrast to that in other studies (for example Coe, 1975; Bourque and Wilson, 1990), where monkeys were encountered only rarely. In addition, only one snare and very few shotgun cartridges were found in the forest, and there was little cultural indication that nocturnal hunting commonly took place. The current absence from Kounounkan of red colobus Procolobus badius badius, a high canopy specialist (Martin, 1991), is attributed to the extent of past deforestation, which may have reduced the forest to such an extent that it was unable to support populations of this disturbance-sensitive species. Allport (1991) reported Picathartes to be hunted elsewhere in Guinea. This is not known to be the case at Kounounkan.

For such an area of forest to be subject to so little apparent hunting pressure is highly unusual. Other studies in Guinea have commented on the high levels of hunting, even within protected areas (Bourque and Wilson, 1990). Other workers, studying well-hunted areas, found mammals so uncommon that they resorted to procuring specimens from hunters (Roche, 1971). The reason(s) for Kounounkan's situation await clarification, although it is possible that the difficulty of access and the fact that part of the forest is considered sacred may be influential. Whatever the basis, the current situation is obviously beneficial to wildlife.

Overall, Kounounkan's wildlife may also have benefited from the disturbance caused by past agricultural activity in the region. Botanical studies indicate that this probably occurred at a low level and for a short time. It has resulted in a mosaic of secondary forest of different ages. Three of the four CTS birds were recorded in such vegetation.

According to O. Crimmen (pers. comm.), 'Amphilius catfishes are adapted to clean, fastflowing mountain environments and are probably vulnerable to changes resulting in sedimentation. Their presence at Kounounkan is probably an indication of the site's minimal disturbance.'

\section{Conservation at Kounounkan}

There is little doubt about the conservation value of Kounounkan. Despite its relict status, the forest appears to be in good condition and is probably a representative sample of a vegetation type that has disappeared from much of Guinea. In addition, it holds populations of a number of globally threatened animal species. Because monkeys and other wildlife do not appear to be regarded as agricultural pests, there is little or none of the human antagonism towards wildlife that, as Mittermeier (1987) noted, can so often hamper conservation efforts. Although actions of local people appear, to date, to have done more to benefit Kounounkan than to harm it, rising rural population levels, the construction of a nearby road and the possibility of encroachment for farming, firewood and hunting mean that a more active approach than hitherto must be adopted to achieve the continuing protection of Kounounkan. The formalization of the forest's status is being planned by the DNFC. Our enquiries revealed that local residents feel positive towards the idea of conserving Kounounkan. In general, much of the enthusiasm appears to be for the economic benefits that, it is believed, will flow from such an initiative. The most obvious way in which this might occur is from eco-tourism. However, at present it is difficult to see how these expectations could be realized, given the lack of infrastructure appropriate for the development of eco-tourism and the difficulty of access to the site

Given the proximity of the capital, its ministries and university, it has been suggested to the DNFC that conservation of natural resources at Kounounkan could be married to instruction, training and environmental education (Barnett, 1993). It is vital that such uses do not conflict with the interests of local people, to which end it is recommended that no ban on hunting be imposed, but that a zoning policy be implemented. The possibility of other sources of income, such as non-timber vegetable forest products, should be investigated, but only once the feasibility of marketing has been thoroughly researched. More im- 
mediately, it is hoped to combine more detailed surveys at Kounounkan with studies of other relict forest patches in the region. Such a programme will help to assess regional conservation priorities and so assist local land resource planning.

\section{Acknowledgments}

We are grateful to Roger Wilson and Amanda Hillier (FFPS), to the staff of the Natural History Museum's mammal section and of the general library, the Zoological Society of London librarians and to Gary Allport (BirdLife International), Ken Smith (RSPB) and Roger Hammond (Living Earth). We express our gratitude to Mammadou Oury Bah (Direction Nationale des Forêts et de la Chasse, Guinea), and to Michael Wilson, Mickael Grut and Catherine Cruveillier of the World Bank. We also wish to thank Thierno Oumar Diallo, Ahmed Faya Traore, Satenin Sanga and Cherif Bah (from DNFC), Paul Anspach (GTZ), Mamadou Daliou Diallo, the staff of Guinée Ecologie, all those at the Catholic Mission, Conakry and Mammadou Saliou Dialo (our driver). Mr and Mrs Mammadou Bella Sase Balde gave their house and hospitality in Moussaya. Cheikh Oumar Diallo and Gnakoye Lamin made entomological collections at Kounounkan; Oliver Crimmen, Natural History Museum, identified our catfish; and John Dutton reviewed an early draft of this paper. This study was funded entirely by the Flora and Fauna Preservation Society.

\section{References}

Allport, G. 1991. The status and conservation of threatened birds in the Upper Guinea forest. Bird Conservation International, 1, 53-74.

Allport, G., Ausden, M., Hayman, P.V., Robertson, P. and Wood, P. 1989. The Conservation of the Birds of the Gola Forest, Sierra Leone. ICBP Study Report, No. 38. ICBP, Cambridge.

Altenburg, W. and Van Der Kamo, J. 1991. Ornithological Importance of Coastal Wetlands in Guinea. ICBP Study Report, No. 47. ICBP, Cambridge.

Ausden, M. and Wood, P. 1990. The Wildlife of the Western Area Forest, Sierra Leone. Report to the Royal Society for the Protection of Birds, International Council for Bird Preservation and Conservation Society of Sierra Leone.

Barnett, A. (ed.) 1993. Report on a Survey of the Biodiversity, Conservation Value and Management Requirements of the Forest of Kounounkan, Forecariah Prefecture, Republic of Guinea. Unpublished report to the Fauna and Flora Preservation Society, London.

Bellamy, R. 1993. Ethnobotany in Tropical Forests. Expedition Field Techniques, No. 3. Expedition Advisory Centre/Royal Geographical Society, London.

de Bournonville, D. 1967. Le chimpanzé en République de Guinée. Bulletin de l'Institut Fondamental d'Afrique Noir, 29A, 1188-1269.

Bourque, J.D. and Wilson, R. 1990. Guinea Forest Biodiversity Study - Ziama and Diecke Reserves. Unpublished report to IUCN, Gland.

Brosset, A. 1984. Oiseaux migrateurs Européens hivernant dans la partie Guinéenne di Mont Nimba. Alauda, 52, 81-101.

Coe, M.J. 1975. Mammalian ecological studies on Mount Nimba, Liberia. Mammalia, 39, 523-587.

Collar, N.J. and Stuart, S.N. 1985. Threatened Birds of Africa and Related Islands. ICBP/IUCN Red Data Book, Part 1. ICBP/IUCN, Cambridge.

da Cunha, A. and Barnett, A. 1989. Project Uakari: First Report; The Preliminary Survey - Part One, Zoology. Unpublished report to IUCN and RGS.

Cumming, D.H.M., Du Toit, R.F. and Stuart, S.N. 1990. Elephants and Rhinos: Status Survey and Conservation Action Plan. IUCN/SSC African Elephant and Rhino Survival Group, IUCN, Gland.

East, R. 1989. Antelopes: Global Survey and Regional Action Plans. Part 3 - West and Central Africa. IUCN/SSC Antelope Specialist Group.

Falconer, J. 1992. Non-timber products in Ghana's forest zone: issues for forest conservation. In Conservation of West and Central African Rainforests (Eds K. Cleaver, M. Munasinge, M. Dyson, N. Egli, A. Peuxer and F. Wencelius), pp. 177-181. World Bank Environment Paper, No. 1. World Bank, Washington DC.

FAO. 1988. An Interim Report on the State of Forest Resources in Developing Countries. FAO, Rome.

Foster-Turley, P., Macdonald, S. and Mason, C. 1990. Otters: An Action Plan for their Conservation. IUCN/SSC Otter Specialist Group. IUCN, Gland.

Happel, R.E. 1985. Birds of Outamba area, northwest Sierra Leone. Malimbus, 7, 101-102.

Harding, D.P. and Harding, R.S.O. 1982. A preliminary checklist of birds in the Kilimi area of northwest Sierra Leone. Malimbus, 4, 64-68.

IUCN. 1988. Guinea: Conservation of Biological Diversity and Forest Ecosystems. WCMC, Cambridge.

Jeffrey, S. 1977. How Liberia uses wildlife. Oryx, 14, 168-173.

Lamotte, M. 1983. The undermining of Mount Nimba. Ambio, 12, 174-179.

Lee, P.C., Thornback, J. and Bennett, E.L. 1988. Threatened Primates of Africa - The IUCN Red Data 
Book. IUCN, Gland.

MacKinnon, J. and MacKinnon K. 1986. A Review of the Protected Area System in the Afrotropical Realm. IUCN/UNEP, Gland.

Martin, C. 1991. The Rainforests of West Africa: Ecology, Threats, Conservation. Birkhauser, Basel.

Mittermeier, R. 1987. Effects of hunting on rain forest primates. In Primate Conservation and the Tropical Rain Forest (eds C. Marsh and R. Mittermeier). Alan R. Liss, New York.

Morel, G.J. and Morel, M-Y. 1988. Liste des Oiseaux de Guinée. Malimbus, 10, 143-176.

Oates, J.F. 1985. Action Plan for African Primate Conservation: 1986-1990. IUCN/SSC Primate Specialist Group. IUCN, Gland.

Pomeroy, D.E. and Tengecho B. 1986. Studies of birds in a semi-arid area of Kenya, III: the use of 'Timed-Species-Counts' for studying forest bird communities. Journal of Tropical Ecology, 2, 231-247.

Republique de Guinee. 1987. Politique Forestiere et Plan d'Action. Plan d'Action Forestier Tropical, Conakry, Guinee.

Richards, D.K. 1982. Birds of Conakry and Kakoulima, Democratic Republic of Guinea. Malimbus, 4, 93-103.

Robinson, P.T. 1971. Wildlife trends in Liberia and Sierra Leone. Oryx, 11, 117-122.

Roche, J. 1971. Recherches mammalogiques en Guinée forestiere. Bulletin du Musee National d'Histoire Naturelle, 16, 737-781.

Rouanet, R. 1954. Projet de classement de la Forêt de Kounounkan (cercle de Forécariah). Avis du chef du service forestier. [Document no. 1.172/e/f dated 'Kindia 4 Nov. 1954', copy in DNFC archives, Conakry].

Schnell, R. 1968. Guinée. In Conservation of Vegetation of Africa South of the Sahara, Symposium Proceedings at the Sixth Plenary Meeting of AETFAT, Uppsala (eds I. Hedberg and O. Hedberg). Acta Phytogeographica Suecica, 54, 69-72.
Schreiber, A., Wirth, R., Riffel, M. and Van Rompaey, H. 1989. Weasels, Civets, Mongooses and their relatives: An Action Plan for the Conservation of the Mustelids and Viverrids. IUCN/SSC Mustelid and Viverrid Specialist Group. IUCN, Gland.

Sodeinde, O.A. and Adedipe, S.R. 1994. Pangolins in south-west Nigeria - current status and prognosis. Oryx $28,43-50$.

Starin, E.D. 1989. Threats to the monkeys of the Gambia. Oryx, 23, 208-214.

Stuart, S.N. and Adams, R.J. 1990. Biodiversity in Sub-Saharah Africa and its Islands: Conservation, Management and Sustainable Use. IUCN, Cambridge.

Sugiyama, Y. and Soumah, A.G. 1988. Preliminary survey of the distribution and population of chimpanzees in the Republic of Guinea. Primates, 29, 569-574.

Thorbjarnarson, J., Messel, H., King, F.W. and Ross, J.P. 1992. Crocodiles: A Plan for their Conservation. IUCN/SSC Crocodile Specialist Group. IUCN, Gland.

White, F. 1983. Vegetation Map of Africa: A Descriptive Memoir to Accompany the UNESCO/ALTFAT, UNSO Vegetation Map of Africa. UNESCO, Paris.

Wilson, J.R. 1992. Guinea. In The Conservation Atlas of Tropical Forests: Africa (eds J. A. Sayer, C. S. Harcourt and N. M. Collins), pp. 193-199. IUCN, Cambridge.

Adrian Barnett, 38 Hill House Road, Streatham, London SW16 2AQ, UK.

Madeleine Prangley, 1 Langbourne Mansions, Langbourne Avenue, London N6 6PH, UK.

Peter V. Hayman, 10 Park View, Weeting, Brandon, Suffolk IP27 0QD, UK.

Djiramba Diawara, Direction Nationale des Forêt et de la Chasse, Conakry, République de Guinée.

Jeremie Koman, Director, Nimba Research Station, Mt Nimba, République de Guinée. 